\title{
Effect of Steel Fibres on Mechanical Properties of Concrete
}

\author{
G.Nagamma, N.Venkat Rao, Ram Mohan Rao Papolu
}

\begin{abstract}
Steel strands are concrete fortifying material which in association with cements invigorates extra ductile just as administer concrete with temperature and shrinkage break control improve break opposition of concrete. A test examination will be made on M-30 evaluation of cement with a water bond extent 0.50 to examination the compressive quality, flexural quality, split adaptability of steel fiber reinforced cement (SFRC) containing filaments at the degrees $0 \%, 1 \%, 2 \%$ and $3 \%$ volume region of catch tain Steel strands of 60 perspective extent will be used. the data got will be dismembered and differentiated and the strong model ( $0 \%$ fiber).An association between viewpoint proportion versus Compressive quality, perspective proportion versus Flexural quality, and viewpoint proportion versus Split elasticity will be contemplated. A near report will likewise be made among cement and fiber concrete.
\end{abstract}

Keywords : Aspect proportion, Compressive quality, Flexural quality, Split malleable strength, Steel filaments.

\section{INTRODUCTION}

Cement is most strikingly utilized creation material inside the universal because of its capacity to get cast in any structure and figure. It also replaces antique creation substances comprehensive of block and stone masonry. The vitality and toughness of cement might be altered by methods for making legitimate changes in its Ingredients like bond mix and water and by strategy for including a few unprecedented segments. Accordingly Concrete may be fittingly capable for an enormous blend of uses. The nearness of miniaturized scale splits inside the mortar-blend interface is responsible for the instilled shaky area of basic cement. The shaky area can be put off with the guide of incorporation of strands in the total. Different sorts of fibers, Such as the ones utilized in standard composite materials can be added into the strong aggregate to improvement its Toughness, or ability to restrict split advancement.

Revised Manuscript Received on December 30, 2019.

* Correspondence Author

G.Nagamma*, Student M.Tech Structural Engineering Department Of Civil Engineering, Institute Of Aeronautical Engineering, Dundigal, Hyderabad, (Telangana), India.

N.Venkat Rao, Associate professor, Department of Civil Engineering Institute of Aeronautical Engineering (Autonomous), Dundigal, Hyderabad(Telangana), India.

Dr. Ram Mohan Rao Papolu, Professor and Head Department Civil Engineering Institute of Aeronautical Engineering (Autonomous), Dundigal, Hyderabad, (Telangana), India.

(C) The Authors. Published by Blue Eyes Intelligence Engineering and Sciences Publication (BEIESP). This is an open access article under the CC-BY-NC-ND license http://creativecommons.org/licenses/by-nc-nd/4.0/
The fibber help to move hundreds at the inward littler scale breaks. Such a Concrete is suggested as fiber-upheld bond (frc). Plain bond cement is most extreme generally utilized material for making of changed frameworks, anyway it experiences various Drawbacks comprehensive of low rigidity, Brittleness and unstable solid spread and espresso break obstruction.

Adding metallic strands to clear bond solid impacts in upgrading auxiliary homes, for example, compressive quality, Split elasticity, Flexible Strength, Ductility additionally expanded by means of including metallic fiber concrete. Henceforth Steel Fiber Reinforced Concrete (SFRC) has been demonstrated as a trustworthy composite development material having propelled execution attributes thinks about to ordinary solid characteristics.

SFRC is the solid made with water powered concrete containing top notch and coarse totals and discrete strands. In SFRC loads of little strands are scattered and apportioned arbitrarily inside the solid all through mixing and thus improve solid habitations. The exact homes of SFRC inform the utilization concerning such texture for making basic applications with and without conventional internal fortification. The utilization of SFRC is, as a result, explicitly suitable for frameworks when they are exposed to loads over the functionality, limitation country in structure and shear and keeping in mind that revealed to impact and dynamic powers as they happen underneath seismic development. The filaments help to turn the majority on the inward miniaturized scale splits.

Primary driver for settling on metallic fiber is;it has higher modulus of flexibility than cement. For the most part, if the modulus of versatility of the fiber is higher than the grid, they help to convey the weight by utilizing developing the rigidity of the materials.

Hypothetically, there are 3 parameters which affect the building properties of fiber fortified cement

1. Steel filaments itself by utilizing contemplating kind, geometry, issue proportion, degree portion, direction and conveyance of Steel strands in cement.

2. Lattice by utilizing considering power and greatest mix size utilized, water/concrete proportion, kind of bond and advantageous cementations material.

3. Model by methods for contemplating the estimations, geometry, and system of preparation of the specimen.

Fiber is a small bit of invigorating material having certain trademark properties. they can be round or level. The fiber is routinely delineated by a beneficial parameter called perspective degree. The perspective degree of the fiber is the degree of its length to its width. Perspective degree ranges from 30 to 150 . 


\section{METHODOLOGY}

\section{A. Material used}

The Material Used for this investigational exertion are

\section{1) Cement}

Cement grade of OPC 53 with specific gravity of 3.14 is used in this work, is collected for local cement traders, Hyderabad, Telanagana.

2) Fine Aggregate

Fine sand of size less than $4.75 \mathrm{~mm}$ is used in this work, which is collected for local traders, Hyderabad, Telanagana.

\section{3) Coarse Aggregate}

Coarse aggregate of size $20 \mathrm{~mm}$ is used in this work, is collected for local traders, Hyderabad, Telanagana.

\section{4) Water}

Water is collected form tube wells.

\section{5) Steel fibers}

In this experiment Hook tain dramix stuck Steel strands have been utilized. The angle proportion embraced were 60 , having length of $30 \mathrm{~mm}$ with measurement $0.50 \mathrm{~mm}$, is gathered for nearby vendor, Hyderabad, Telanagana.

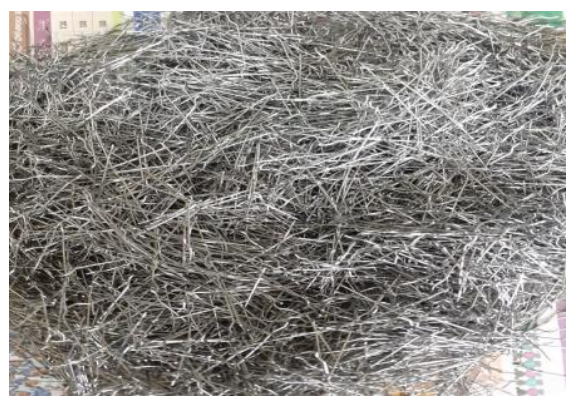

Figure.1:Steel fibres

\section{B.Experimental Procedure}

Solid blend of M 30 is set up with water bond proportion of 0.50 .Overall 36 3D squares of size $150150 \times 150 \mathrm{~mm}, 36$ chambers of dia $15 \mathrm{~mm}$ and ht of $30 \mathrm{~mm}$ and 36 light emissions 100x100x500mm are casted and restored for 7,14 and 28days after 24 hrs of putting the blend in molds. Subsequent to relieving of determined days the examples were tried for quality.

\section{C.Experimental Investigations}

\section{Compressive quality test:}

$0 \%, 1 \% 2 \%$ and $3 \%$ fibers irregularity is used in each mix, and put in molds. Vibration was given to the molds utilizing table vibrator, the summit surface of the model was leveled and wrapped up. Following 24 hours the models were demoulded and were moved to moderating tank for 7 days,14 days and 28 days, these 3D shapes were tried bleeding edge weight testing machine as shown by I.S. 516-1959. The error weight was noted. In each class3 3D shapes were endeavored and their standard worth is spoken to. The compressive quality was typical as looks for after.

Compressive quality $(\mathrm{MPa})=\mathrm{P} / \mathrm{A}$

Where. P-Failure Load(KN)

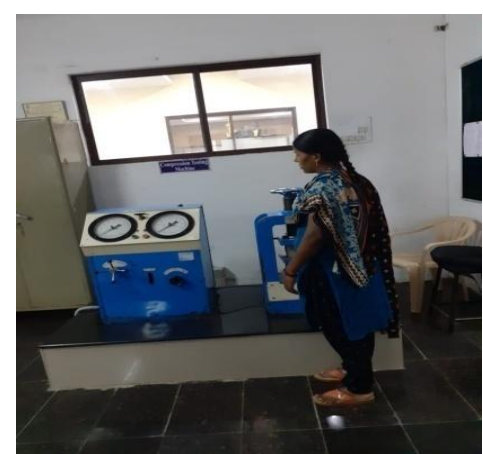

Figure.2:compressive strength test

\section{Split tensile strength test:}

For Split inflexible nature test, chamber examples of estimation $150 \mathrm{~mm}$ partition transversely finished and 300 mm length were hurled. The models were demoulded following 24 hours of hurling and were moved to alleviating tank for 7days, 14days, and 28 days. These models were endeavored under strain testing machine. In each class three chambers were endeavored and their normal worth is spoken to. Split Tensile quality was intentional as looks for after as Split Tensile quality $(\mathrm{MPa})=2 \mathrm{P} / \pi \mathrm{DL}$,

Where,

$\mathrm{P}=$ disappointment load,

$\mathrm{D}=$ width of chamber,

$\mathrm{L}=$ length of chamber

\section{Flexural strength test:}

For flexural quality test shaft occasions of estimation 150x150x700 mm were hurled. The models were demoulded following 24 hours of hurling and were moved to facilitating tank where in they were permitted to answer for 7days,14days,and 28 days. These flexural quality models were endeavored under two point stacking as shown by I.S. 516-1959, over a productive extent of $400 \mathrm{~mm}$ on Flexural testing machine. Weight and differentiating redirections were noted up with thwarted expectation. In each class three bars were endeavored and their common worth is spoken to. The flexural quality was settled as looks for after.

Flexural quality $(\mathrm{MPa})=(\mathrm{P} \times \mathrm{L}) /(\mathrm{b} \times \mathrm{d} 2)$,

Where, $\mathrm{P}=$ Failure load,

$\mathrm{L}=$ Center to focus separation between the help $=600 \mathrm{~mm}$,

$\mathrm{b}=$ width of specimen $=150 \mathrm{~mm}$,

$\mathrm{d}=$ centrality of specimen $=150 \mathrm{~mm}$.

\section{EXPERIMENTAL RESULTS}

Table 1: Compressive strength values

\begin{tabular}{|c|c|l|l|l|}
\hline S.no & $\begin{array}{c}\text { percentage of } \\
\text { steel fiber } \\
\text { reinforced } \\
\text { concrete }\end{array}$ & $\begin{array}{l}\text { 7days } \\
(\mathrm{N} / \mathrm{mm} 2)\end{array}$ & $\begin{array}{l}\text { 14days } \\
(\mathrm{N} / \mathrm{mm} 2)\end{array}$ & $\begin{array}{l}\text { 28days } \\
(\mathrm{N} / \mathrm{mm} 2)\end{array}$ \\
\hline 1 & $\begin{array}{c}0 \% \text { of steel } \\
\text { fiber }\end{array}$ & 23.62 & 25.55 & 28.14 \\
\hline 2 & $\begin{array}{c}\text { 1\% of steel } \\
\text { fiber }\end{array}$ & 28.14 & 30.88 & 34.07 \\
\hline 3 & $\begin{array}{c}2 \% \text { of steel } \\
\text { fiber }\end{array}$ & 29.03 & 31.77 & 36.07 \\
\hline 4 & $\begin{array}{c}3 \% \text { of steel } \\
\text { fiber }\end{array}$ & 29.55 & 33.47 & 37.92 \\
\hline
\end{tabular}




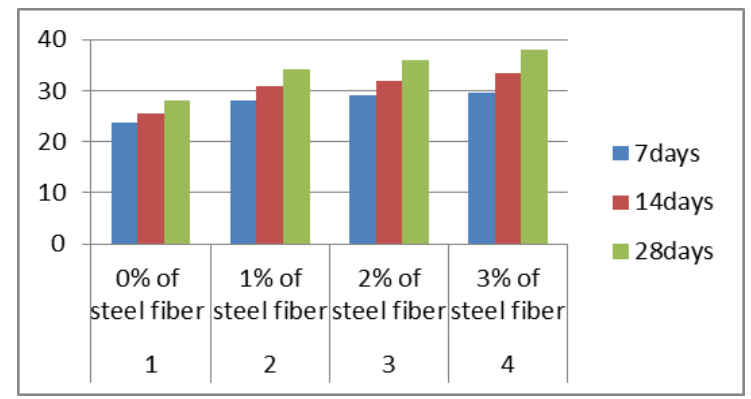

Figure.3: Compressive strength graph

Table. 2: split tensile strength values

\begin{tabular}{|l|l|l|l|l|}
\hline S.NO & $\begin{array}{l}\text { Percentage of } \\
\text { steel fiber }\end{array}$ & $\begin{array}{l}\text { 7days } \\
(\mathrm{N} / \mathrm{mm} 2)\end{array}$ & $\begin{array}{l}\text { 14days } \\
(\mathrm{N} / \mathrm{mm} 2)\end{array}$ & $\begin{array}{l}28 \text { days } \\
(\mathrm{N} / \mathrm{mm} 2)\end{array}$ \\
\hline 1 & $0 \%$ of steel fiber & 2.14 & 2.48 & 2.77 \\
\hline 2 & $1 \%$ of steel fiber & 2.42 & 2.79 & 3.32 \\
\hline 3 & $2 \%$ of steel fiber & 2.58 & 2.86 & 3.5 \\
\hline 4 & $3 \%$ of steel fiber & 2.7 & 2.99 & 3.76 \\
\hline
\end{tabular}

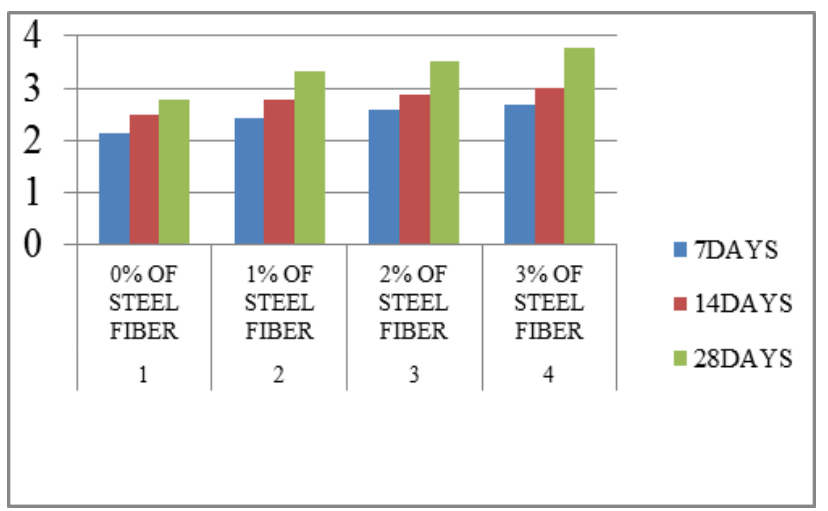

Figure.4:split tensile strength graph

Table.3: flexural strength values

\begin{tabular}{|l|l|l|l|l|}
\hline $\begin{array}{l}\text { S } \\
\text { NO }\end{array}$ & $\begin{array}{l}\text { Percentage of } \\
\text { steel fiber }\end{array}$ & $\begin{array}{l}\text { 7days } \\
(\mathrm{N} / \mathrm{mm} 2)\end{array}$ & $\begin{array}{l}\text { 14days } \\
(\mathrm{N} / \mathrm{mm} 2)\end{array}$ & $\begin{array}{l}\text { 28days } \\
(\mathrm{N} / \mathrm{mm} 2)\end{array}$ \\
\hline 1 & $0 \%$ of steel fiber & 3.37 & 4.26 & 4.97 \\
\hline 2 & $1 \%$ of steel fiber & 3.76 & 4.65 & 5.21 \\
\hline 3 & $2 \%$ of steel fiber & 4.14 & 4.82 & 5.57 \\
\hline 4 & $3 \%$ of steel fiber & 4.32 & 4.94 & 5.92 \\
\hline
\end{tabular}

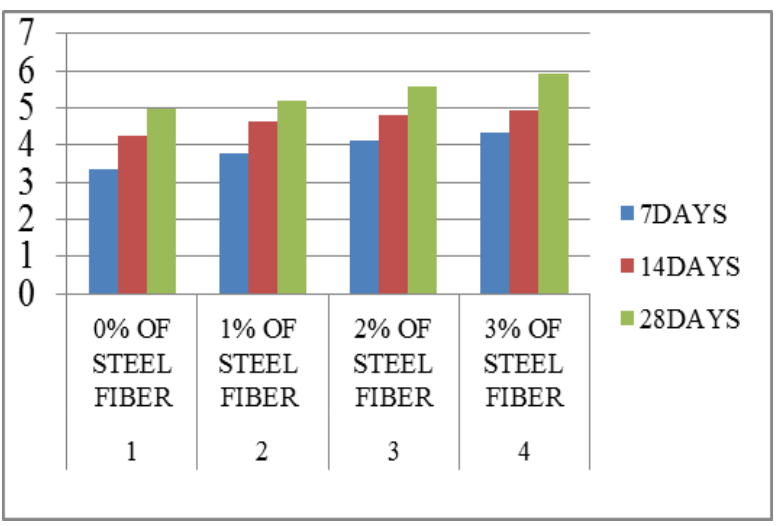

Figure.5: flexural strength graph

\section{CONCLUSION}

The going with conclusions could be drawn from the typical thought.

1. It is seen that compressive strength, split tensile strength and flexural strength are on higher side for 3\% fibres as compared to that fabricate from $0 \%, 1 \%$ and $2 \%$ fibres

2. It is seen that there is an increment in compressive quality from $11 \%$ to $24 \%$ with advancement of steel filaments.

3. It is seen that flexural quality is amplified from $12 \%$ to $14 \%$ with advancement of Steel strands.

4. It is seen that split rigidity is extended from $3 \%$ to $41 \%$ with augmentation of steel strands.

\section{REFERENCES}

1. Ganeshan N et al, (2007), steel fiber enlivened extraordinary bond for seismic safe structure ${ }^{\text {ec }}$ Civil Engineering and improvement Review, December 2007, pp 54-63

2. Bhikshma V, Ravande Kishor and Nitturkar Kalidas (2005)," Mechanical properties of fiber fortified decision security „Recent moves in bond and improvement tech ${ }^{\text {ee }} 6-8$ Jan 2005, Chennai, pp 23-33

3. Balaguru P and Najm H (2004), "Winning degree of fiber-strengthened mixing with high-volume fiber groups", Material Journal, volume 101, number 4, 1 July 2004 pp281-286

4. Ghavami, K., Rodrigues, C. e. Paciornik, S., "Bamboo: Functionally Qualified Composite Material", Asian Journal of Civil Engineering (building and hotel), vol. 4. (2003), p. 1-10

5. Tensing D, Jeminah and Jaygopal LS (2003) "Permeability inspects steel fiber strengthened concrete and the effect of flying slag" National class on the progression of the materials made, 14-15 February 2003.

6. Madan S. K., Rajeshkumar G. likewise, Sign S.P., "Steel strands overriding the help of the framework for significant cut RCC shafts", Asian Journal of Civil Engineering Building and Housing), vol. 8, n. 5 (2007), p. 479-489

7. Damgir R.M. in addition, Ishaque M.I.M (2003) "Effect of silica smoke and steel fiber compound on the quality properties of the highest point of the line joint", system INCONTEST 2003, Coimbatore, 10-12 September 2003, pp281-286

8. Raghuprasad .P.S, Ravindranatha (2003) "Appraisal of the check of the possibility of the bowing of the solid fiber bond ambushed", INCONTEST 2003 strategy, Coimbatore, 10-12 September 2003, pp 403-408

9. S.K. Madan, g. Rajesh Kumar and S.P. Singh, "Exchange of Steel Wires from the Strength of the Network for a Significant Axis in the RCC Court", Asian Journal of Civil Engineering (Building and Housing), vol. 8, n. 56 (2007), p. 479-489

10. Permalatha J and Govindraj V (2003) "Exploratory tests on fiber-reinforced bond" "INCONTEST 2003 Procedure, Coimbatore, 10-12 September 2003, pp. 462-468

11. Bayasi, Z and Zeng, J. (1993) "Properties of strengthened bond with polypropylene fiber" "ACI Materials Journal, Novl-Dec 1993, vol. 90 No 6, pp. 605-610

\section{AUTHORS PROFILE}

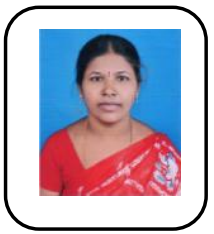

G.Nagamma, is student M.Tech in structura engineering in Department of civil engineering, institute of aeronautical engineering, dundigal, Hyderabad, telangana. She has received graduation in B.Tech Civil Engineering, from JNTU Hderabad, telangana ,India.

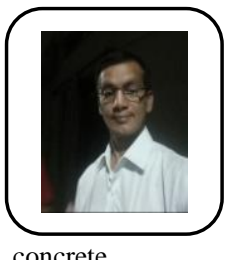

N.Venkat Rao working as Associate professor in the Department of Civil Engineering in institute of aeronautical engineering (Autonomous), Dundigal, Hyderabad. He obtained Masters from JNTU, Hyderabad. He published more 30 papers in both International and national journals and conferences, His area of research is materials, concrete, special 
Effect of Steel Fibres on Mechanical Properties of Concrete

Dr. Ram Mohan Rao Papolu, working as Professor and Head of the Department in Civil Engineering Department, Institute of Aeronautical Engineering (Autonomous), Dundigal, Hyderabad. He obtained PhD from Sri Venkateswara University, Thirupathi in 1993 , M.Tech from Mangalore University in 1986.He published more than 30 International and National journals and conferences and also a member of FIE, MISTE, ISNT, ASCE (I), ISH, MISCEE. His area of research is Water Resource Engineering and Hydraulics. 